\title{
Hydrogeological Study of the Aquifer System in Central Tunisia: New System Structuring of Horchane Aquifers
}

\author{
Soumaya Chaibi, Wanissa Aydi, Moncef Chalbaoui \\ Laboratory Water, Energy and Environment, National School of Engineers of Sfax, Sfax City, Tunisia \\ Email: chaibisoum@hotmail.fr
}

Received January 18, 2013; revised February 19, 2013; accepted March 17, 2013

Copyright (C) 2013 Soumaya Chaibi et al. This is an open access article distributed under the Creative Commons Attribution License, which permits unrestricted use, distribution, and reproduction in any medium, provided the original work is properly cited.

\begin{abstract}
Hydrogeological investigations, tectonics and seismic reflection show the complexity of the Horchane groundwater and drainage possibilities with neighboring groundwater in central Tunisia. Seismic reflection lines intersecting the region show the role of halokinetic movements, by the intrusion along preexisting faults, in the restructuring of the hydrogeological basin. The salt domes associated with a chaotic facies at the base of outcrops, that limit the Horchane basin, puch to outcrops the areas of recharge area. Geoelectric section shows the anisotropy and the importance of MioPlio-Quaternary (MPQ) sediment along the gutters, between the outcrops of El Hafay and Kebar on the one hand, and outcrops of Kebar and Majoura on the other. These gutters are communicated with channels that facilitate drainage of the Horchane complex groundwater by that Gammouda in North-East and Braga in East. The results of this study clearly indicate the important role of the geology in the restructuring of groundwater basins, through early halokinetic movements. (i.e. halokinetic movements). The aquifer geometry is controlled by the ascent of Triassic salt material, from the Middle Jurassic, in central Tunisia.
\end{abstract}

Keywords: Groundwater; Hydrogeological Basin; Halokinetic Movement; Aquifer Geometry; Water Recharge; Drainage; Filling; Triassic Salt Material

\section{Introduction}

The Horchane Basin is situated in the Sidi Bouzid region in the central Tunisia (Figure 1), and it is characterized by a Mediterranean semi-arid to arid climate with irregular annual rainfall not exceeding $350 \mathrm{~mm} /$ year and long dry periods. Use of groundwater is increasing in order to meet the demand for domestic, agricultural, and Industrial needs. Therefore deep aquifer exploration and exploitation become a necessity in this area.

In central Tunisia, water tables are facing problems of overdrafts due to poor estimation of their architecture [1-3], their preferred areas of recharge and their outlets. The Horchane basin has undergone a complex and polyphase structural history since middle Mesozoic time [4-7] that is marked by North-Sud and NE-SW faults [5,8-11]. Recent studies [4,12-16] have indicated that the anticline structures of the central Atlas of Tunisia as a Triassic salt diaper at different evolutionary stages, such as El Hafay, Majoura and Souinia outcrops, where as the present plain structures should relate to corresponding compensation depocentre gutters. Triassic intrusions induced by strikeslip movements contributed to restructure the hydro- geological basins.

Seismic data have been traditionally thought of as regional screening tools capable of providing basin definitions and basement mapping. However, in recent years, the application of potential field data has been greatly expanded to include global in this study, we used data from seismic reflection correlated with tectonic and hydrogeological data to track architecture of the groundwater as well as opportunities Horchane drainage with neighboring aquifers.

The seismic reflection method was selected as the geophysical method that would give a regional picture of the subsurface geology and geometry of hydrogeological basin.

The characterization of the Horchane complex aquifer was developed and applied to deeper aquifers with combining all data, especially the geophysical, tectonic and hydrodynamic ones.

\section{Study Area Setting}

The study area called Horchane Basin is located west of central Tunisia, it is a basin bounded by the NE-SW ori- 


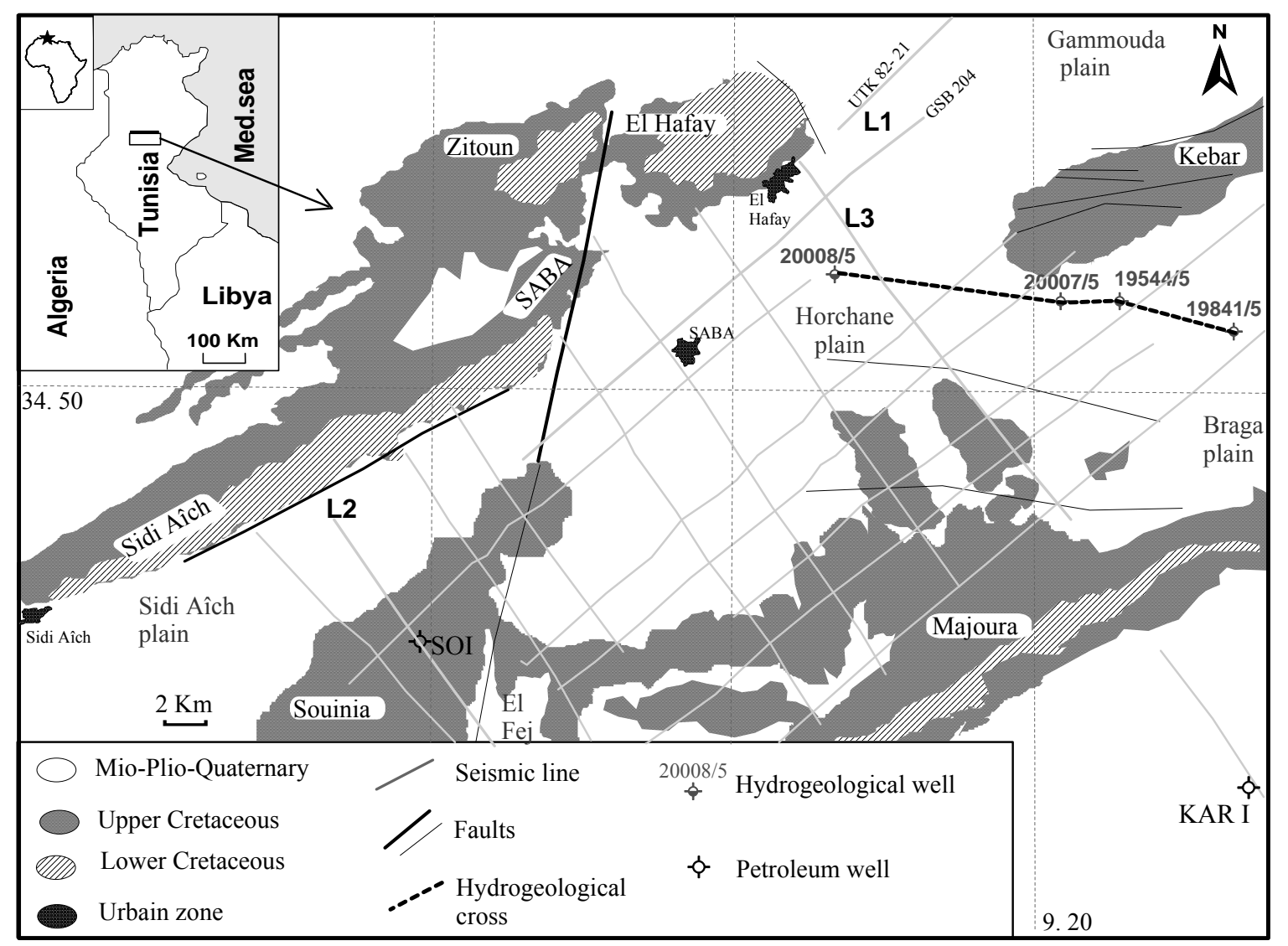

Figure 1. Geologic, seismic profile and location of the study area.

ented anticlines (Figure 1). Lower cretaceous sediments outcrop as anticline cores of Sidi Aîch, Sidi Ali Ben Aoun (SABA), Bir El Hafay, Zitoun, Kebar and Majoura-Meloussi mountains. North-south, NE-SW and NWSE faults (Figure 1) that have been reactivated since the upper Triassic-lower Jurassic rifting $[5,9,11,15]$ bound different tectonic blocks of Horchane area and are often associated with Triassic salt-pillow and domes that responsible for hydrogeological basin structuring.

The area is characterized by a semi-arid climate; it is by annual rainfall about $236 \mathrm{~mm} /$ year over the period 1974-2011, those are significant between December and April. The temperature varies seasonally with a winter minimum of $15^{\circ} \mathrm{C}$ and a summer maximum of $30^{\circ} \mathrm{C}[17$, 18]. The drainage system is dominated by the Oued El Maksem which the flow appears only during the highest flood [19].

The syncline Horchane lodges levels aquifers that extend from the Jurassic to the Mio-Plio-Quaternary (MPQ), those operated by citizens (drinking water, agriculture and domestic activities) are the upper Turonian carbonate layers and Neogene sandy clay layers. The semi-permeable levels between the Miocene and Cretaceous [1,2022] allow considering aquifers as they lodged a single complex multilayer aquifer groundwater (Figure 2). The geometry of this complex aquifer depends on the early halokinetic movements that characterize the Horchane basin from the Middle Jurassic [4,9,23].

\section{Materials and Methods}

The hydrogeological study requires not only the use of conventional methods (rainfall, piezometric, lithology, hydrodynamics...), but also methods of investigation using modern geophysics.

The objective of the hydrogeological study is to understand the functioning of an aquifer and to estimate the different characteristics that make each of the tools information and are implemented through a procedure adopted.

The seismic reflection survey method was selected as the geophysical method that would give a regional picture of the subsurface geology and groundwater geometry before making extensive surveys by the geoelectrical method.

The seismic reflection is a method of exploration geophysics which the properties of the earth's subsurface from reflected seismic waves $[11,24]$. These will be reflected when they encounter a boundary between two different materials with different acoustic impedances. 


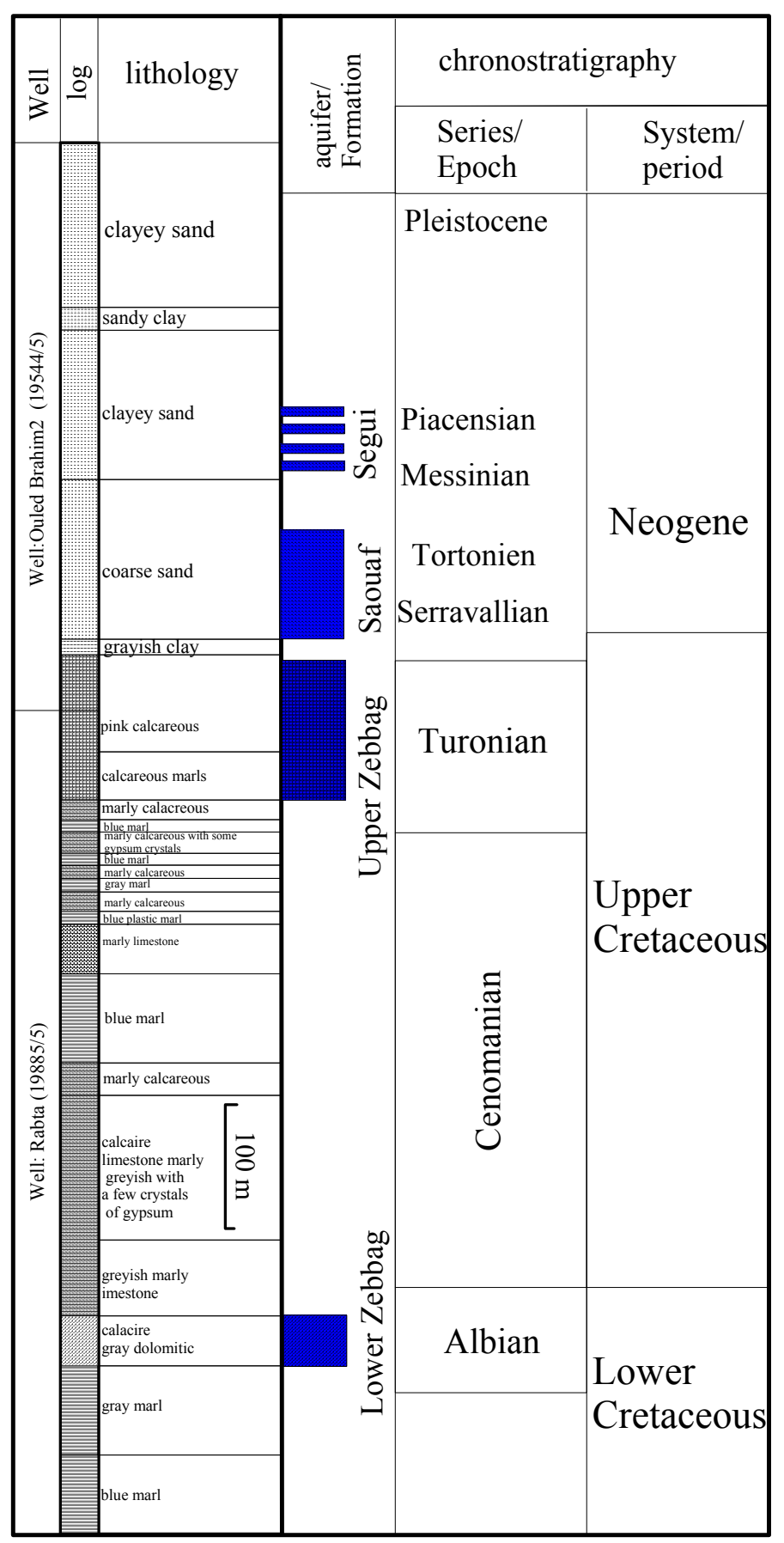

Figure 2. Litho-hydro-stratigraphic column of Horchane basin and surrounding area.

They are detected, on land, using geophone [25]. The recorded signals are plotted on a seismic section after significant amounts of processing [26,27]: demultiplexing, filtring, deconvolution, velocity analysis, stacking, migration...

We propose to use the seismic reflection profiles to study the lateral location and geometry of the Upper Cretaceous units (Figure 2). Recent studies [15,20,21, 29-31], have shown that seismic refection profiling is used in hydrogeology for several objectives: the delineation of lithological units; the investigation of thickness and nature of covering layer; the estimation of depth extension and thickness of the aquifers; and the mapping of discontinuation zones like fractures and faults.

Whereas, the geophysical electrical measurements (geoelectrical) are largely applied in the study of diverse underground irregularities. The rocks and geological formations may be distinguished by the way they conduct 
electricity, specifically by their physical property called electrical resistivity. The electrical current consists of the movement of electrical charge, which is represented by electrons or ions. Ions move within the fluids in the rock pores. The experimental results show that the largest contribution to the movement of electrical current through rocks and geological formations comes from their water content. Considering the last decade scientific performance on the ability to process, display and interpret data, the geoelectrical measurements have started to be applied in numerous domains, such as the geo-science, but also in domains such as hydro-geology, as well as in environmental protection studies [31].

Subsurface structuring and groundwater geometry were determinate by using seismic lines across the study area, geo-electrical sections, petroleum wells and hydrogeological wells. The seismic data consist of 16 seismic lines provided by Company of Petroleum Activities (ETAP) for petroleum exploration in 1983. They are oriented roughly NE-SW and NW-SE (Figure 1). Two petroleum wells (Souinia SOI and Kharrouba KARI) were also used to calibrate seismic facies.

Geometry of hydro geological Horchane basin (upper Turonian and MPQ) associated with salt Triassic activities is studied here. The MPQ geometry is identified by geoelectrical section provided by the general direction of Water Resources (DGRE) Tunis for electrical surveys conducted in 1978, the total number of measured points is 111 and the electrical sounding were carried out following the Schlumberger quadrupole with $2000 \mathrm{~m} \mathrm{AB}$ line length [32-34]. Five hydrogeological wells and six electrical sounding were used to determinate the MPQ levels lithology.

The groundwater flow is determined by piezometric measurements consisting 42 hydrogeological pumped wells used for irrigation. Their depths ranged from $140 \mathrm{~m}$ to $620 \mathrm{~m}$. This study was used to confirm the assumptions made by the seismic approach, to determine the geometry of the groundwater basin.

\section{Results}

\subsection{Seismic Approach}

The seismic section L1 crosses the study area in a direction NE-SW (Figures 1 and 3). It shows, in the same direction, the structure with a basin at the base of depocentre in Gammouda. Indeed, the entire sedimentary sequence from the Jurassic to the MPQ sinks from SW to NE. The observed dip is in favor of drainage of Horchane complex aquifer by that of Gammouda. To the SW, a relatively high zone of Sidi Ali Ben Aoun (SABA) fault marks a hydrogeological boundary between the Horchane complex aquifer and Sidi Aich. The Upper Cretaceous seismic horizons show a bevel and onlap aggradation with a chaotic facies at the SABA fault; this confirms the structure of a shared area for this north-south tectonic event.

To North-East, El Hafay gutter is filled by relatively significant thicknesses of MPQ levels. This transit, between the Horchane basin and that of Gammouda, is affected by subsurface faults that explain the instability of the Triassic salt dome at the base of $\mathrm{Dj}$. El Hafay.
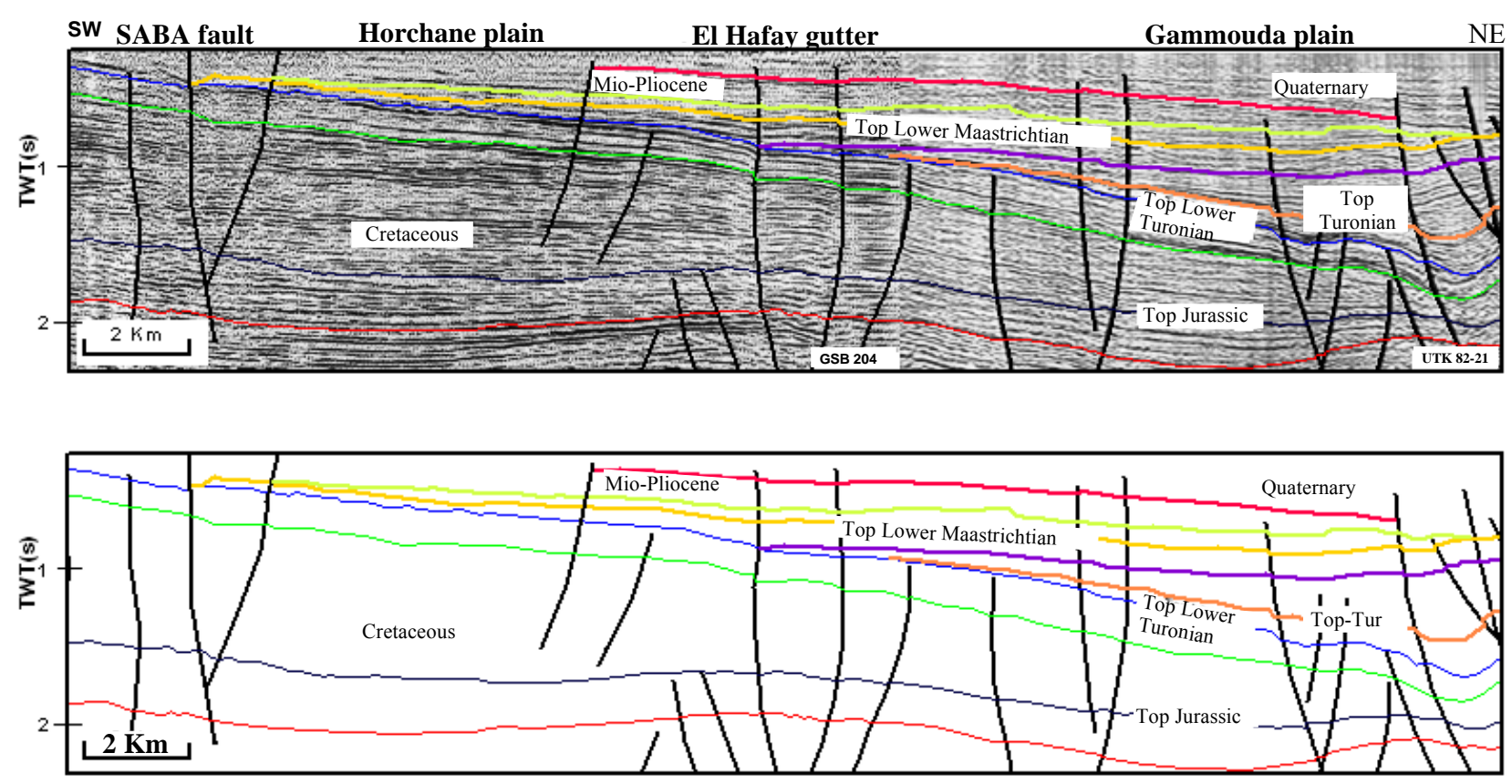

Figure 3. Seismic profile section L1 (location on Figure 1) inside El Hafay gutter (T. Zouaghi, 2008, modified). 
The seismic section L2 of NW-SE direction, calibrated to the Souinia 1 Well (SOI) [9] (Figures 1 and 4), shows the effect of the Triassic salt rise layer that reached the stage of salt pillow which causes the outcrop of upper Turonian limestones (upper Zebbag), where structuring Souinia as the hydrogeological limit between the Horchane basin and that of Sidi Aich. The same section shows the importance of the faults corridor, associated with the SABA fault. On whose behalf the Triassic salt layer up, to contribute to the fragmentation of hydrogeological basin.

The seismic line L3 of NW-SE direction shows the effect of salt domes mobilized along the NW-SE faults of Majoura (Figures 1 and 5). Indeed, the Horchane basin widens to the NW with significant thicknesses of Jurassic sedimentary levels, lower Cretaceous levels and including the MPQ, this last level disappears in the Majoura region in the profile of the Upper Cretaceous levels. The

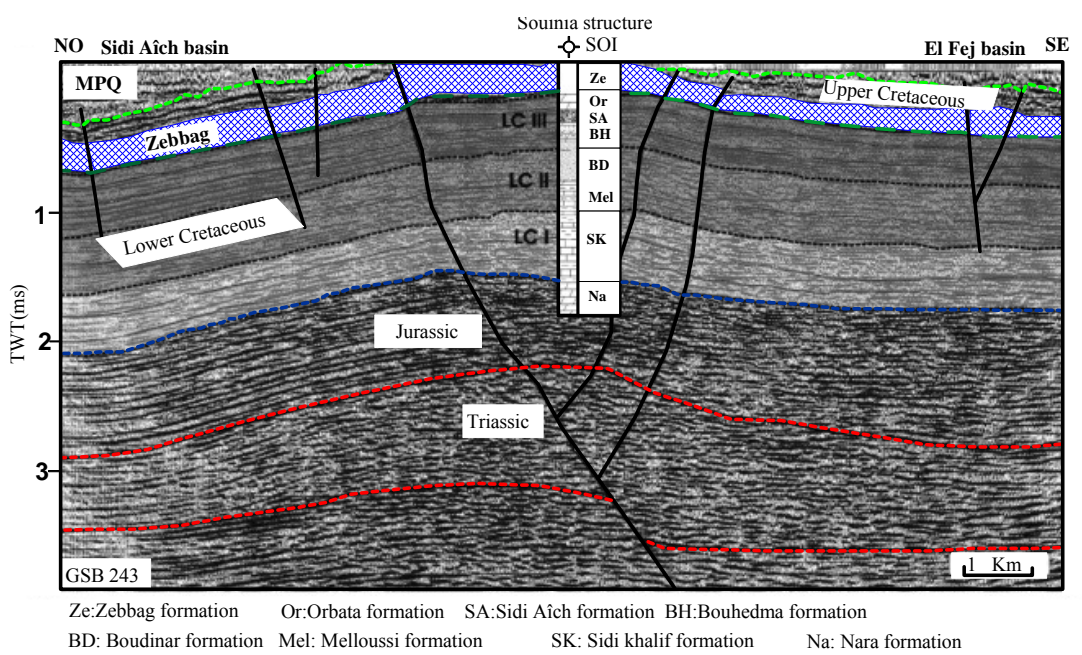

Figure 4. Interpreted seismic section L2 showing the basin of Sidi Aîch and El Fej basin the salt pillow above the Souinia well (H. Azaiez, 2008, modified).
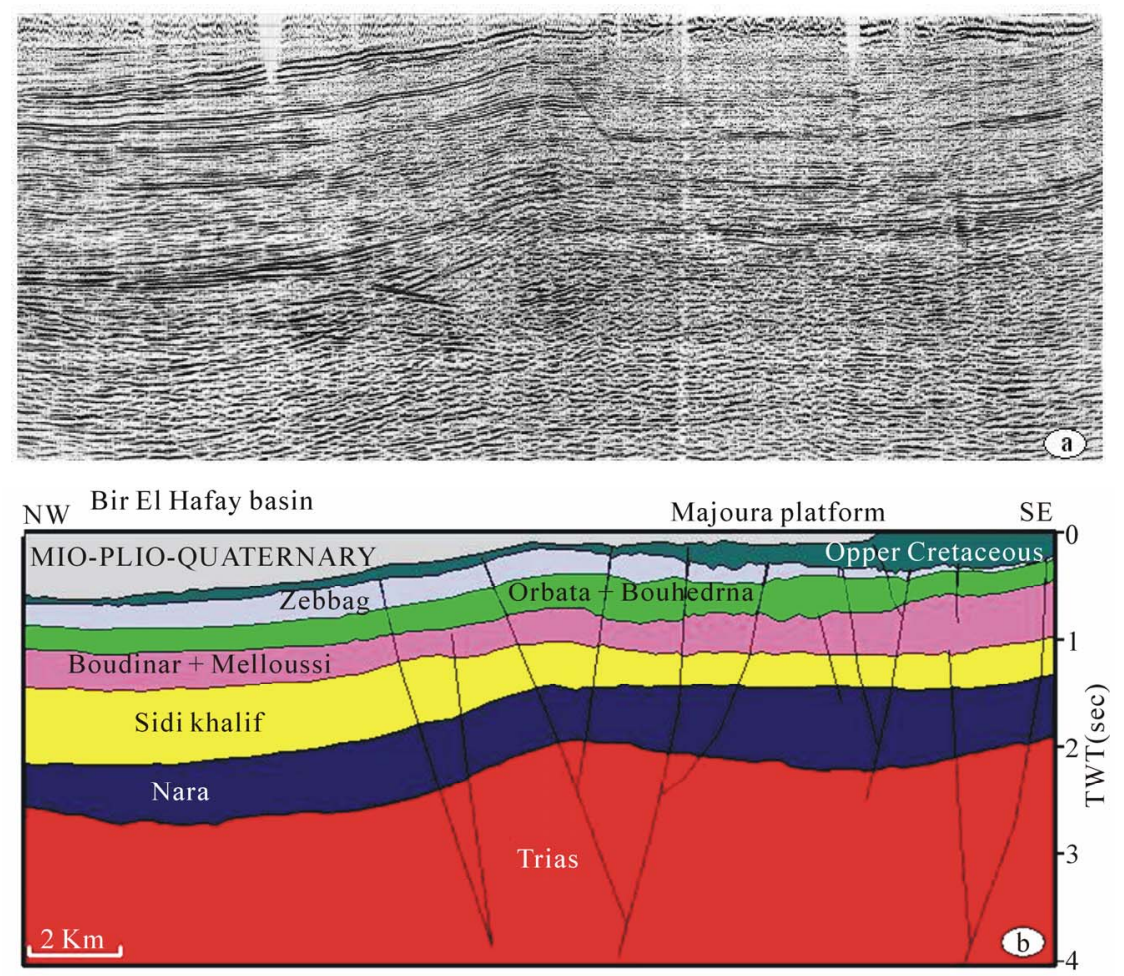

Figure 5. (a): seismic profile L3; (b): Interpreted seismic section L3, showing the lateral structure of studied area through Bir El Hafay basin and Majoura platform. 
structure of the relatively high Majoura platform has been interpreted as a hydrogeological boundary between Horchane basin and that of Braga eastward.

\subsection{Geoelectric and Hydrogeological Analysis}

Due to lack of seismic reflection study in the MPQ filling, geoelectric sections were used to determinate the complex architecture of Horchane aquifer [35].

The geoelectric NE-SW section G (Figures 1 and 6) shows the heterogeneity in the MPQ filling, it can raise 4 geoelectric levels:

- The first level includes all sub levels resistivity with contrast (4 ohms to $100 \mathrm{ohms}, 5 \mathrm{ohms}$ to $20 \mathrm{ohms}$ ), the second sub level appears to contain Quaternary perched groundwater;

- The second level shows a lateral variation of resistivity (35 ohms to $70 \mathrm{ohms}$ ) which expresses the heterogeneity of facies and that marks the diffuse passage of clay, clay sandy, sandy clay and conglomerate from Mio-Pliocene (MP) to Quaternary. The discontinuous clay sub layers are considered as walls for perch groundwater;

- The third level, less contrasted (5 ohms to $12 \mathrm{ohms}$ ), is conducting. It could be attributed to the MP who lodges the deep Horchane aquifer with predominantly sandy and sandy-clay levels;

- The fourth level shows a variation of resistivity, both vertical and horizontal extensions. The first relatively conductive sub level (20 ohms to $60 \mathrm{ohms}$ ), it would constitute the upper Turonian limestone; the more resistant second level (100 ohms to $200 \mathrm{ohms}$ ) probably marks the Cenomanian limestone with clay and marl alternations. The third resistant sub-level ( $>200 \mathrm{ohms})$ can be attributed to the dolomites of the upper Albian.

Geo-electric G section shows that the anisotropic filling is based on the upper Turonian limestone with a very diffuse transition recorded with very mixed resistivity values. Where confirmed a multilayer aquifer structure for Horchane complex groundwater, which includes lev- els of higher Zebbag formation (Upper Turonian) and those MPQ fillings.

To the SW, the same cup G shows the outcrop of limestone resistant ( $>200$ ohms) the Upper Turonian. This structure marks the southern boundary of the hydrogeological Horchane basin from to that of El Fej.

To the West, the hydrogeological section H (Figures 1 and 7) made between the deepest drilling in the area, it shows the importance of MPQ sedimentary levels that exceeds $500 \mathrm{~m}$ between the the Kebar outcrop and Majoura platform. The dip observed at all filling levels (NW to $\mathrm{SE}$ ) permits the possibility of water flow direction from Horchane to that of Braga, through the Kebar gutter.

\subsection{Piezometric Analysis}

The piezometric head contour map overlaying the Upper Cretaceous outcrops in the region is illustrated in (Figure 8). This map shows for hydrodynamic regions. The first is in the south-western part, in SABA fault, where groundwater flow is diverging in the same zone, where groundwater head is $380 \mathrm{~m}$, it confirms the hypothesis of a hydro geological limit in this area with relatively higher slope. The second hydrodynamic region is an overall flow direction converging from the periphery to the center of the aquifer varying between $335 \mathrm{~m}$ to $315 \mathrm{~m}$. The third hydrodynamic region, in Kebar gutter, is the drainage of the Horchane water from that of Braga eastward, varying between $315 \mathrm{~m}$ to $290 \mathrm{~m}$; this confirms the structure detected by the hydrogeological section $\mathrm{H}$. The forth hydrodynamic region is in the northern part, in the El Hafay basin, where the flow direction is from Horchane basin to that of Gammouda. This direction validates the dip observed in the seismic line L.

\section{Conclusions}

It appears from the seismic study that the complex archi tecture of Horchane aquifer is controlled by the ascent of

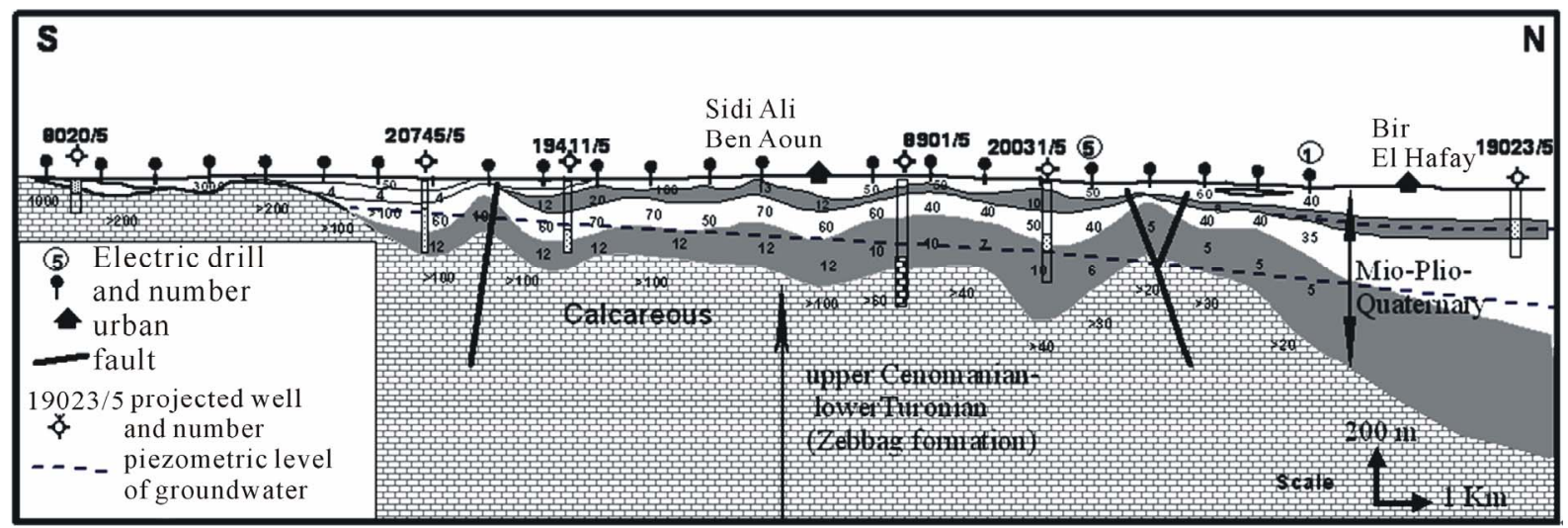

Figure 6. Geoelectrical cross (G) from El Fej basin to that of gammouda (S. Gassara, 1980, modified). 


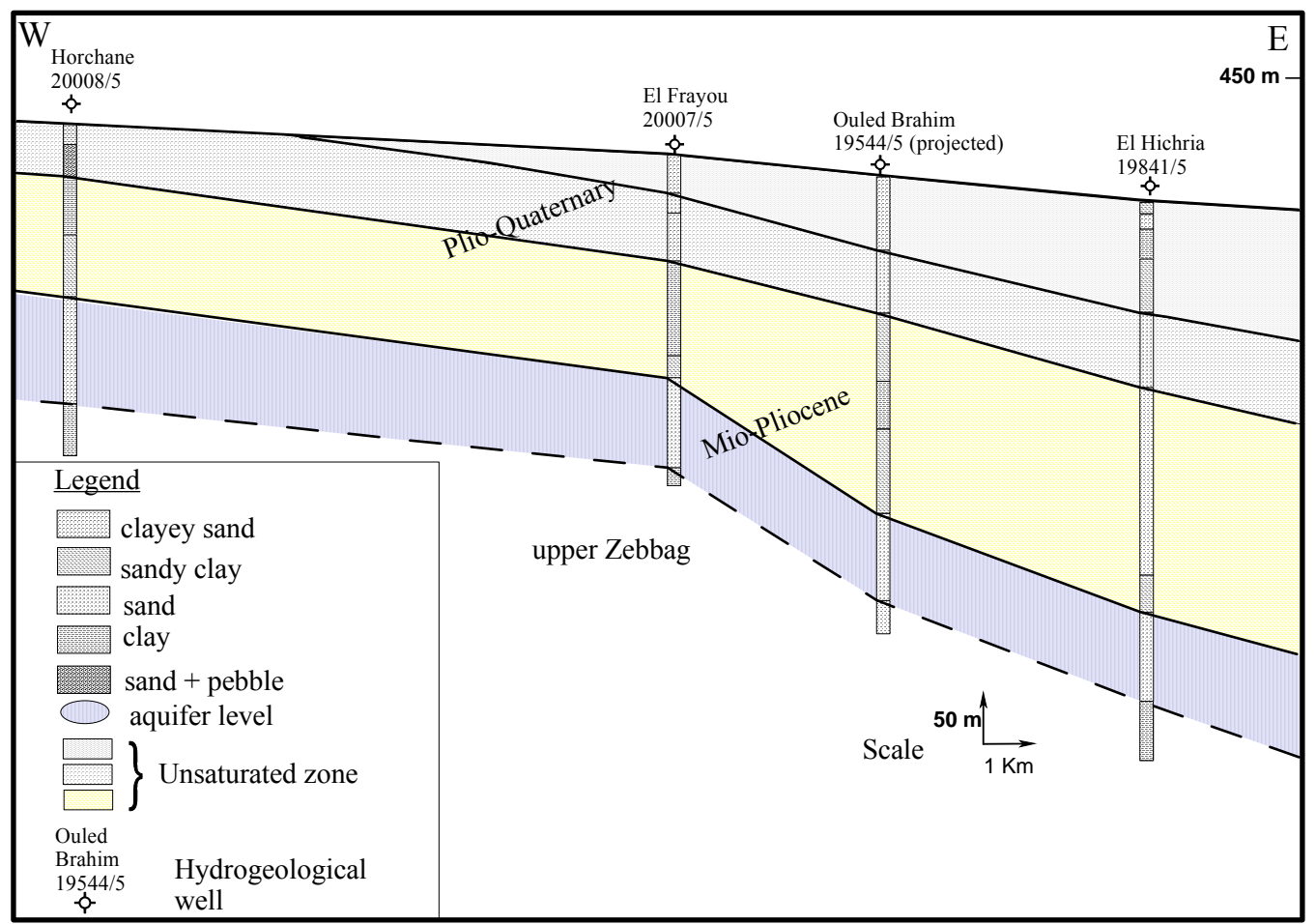

Figure 7. Hydrogeological cross section (H) in studied area (position marked in Figure 1).

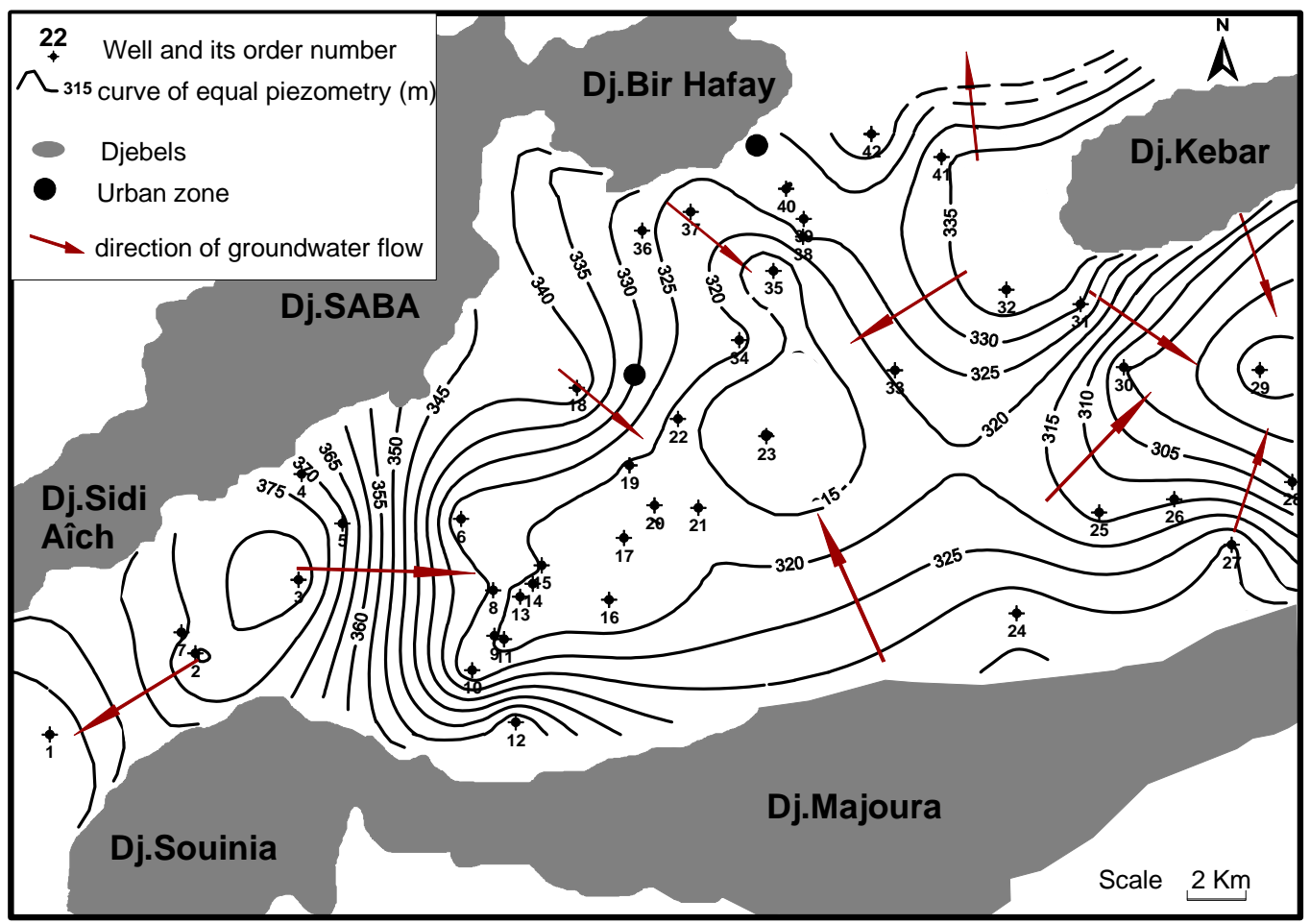

Figure 8. Piezometric map of Horchane complex aquifer (2008).

the salt Triassic material, since the Jurassic, along strikeslip faults. These salt dome structures at the base of outcrops Hafay, Souinia and Majoura generate limits to the hydrogeological basin of Horchane. However, the struc- tures of hydrogeological gutters where the thicknesses of MPQ sediments are important allow communications between the adjacent groundwater layers.

Indeed, the piezometric map shows that gutter El 
Hafay promote drainage of Horchane complex aquifer by that of Gammouda to NE, while the Kebar gutter allow drainage of the same complex in the east from Braga aquifer. The bulge created by the early intrusion of the halokinetic movements, along the SABA faults and Souinia structure, constitute a limit to the Horchane complex aquifer relative to that of Sidi Aich (in SW) and relative to that of El Fej (in the south), which removes the opportunity for exchange of groundwater.

\section{REFERENCES}

[1] H. Chekhma, "Etudestratigraphique, Sédimentologique et Tectonique de la Région de Bir El Hafey-Sidi Ali Ben Aoun (Tunisie Centrale)," Université de Tunis-2, Thèse 1996, p. 261.

[2] P. F. Burollet, "Contribution à l'Etude Stratigraphique de la Tunisie Centrale," Annales des Mines et de la Geologie, Vol. 18, No. 3, 1956, p. 350.

[3] T. Zouaghi, M. Bédir and M. H. Inoubli, "2D Seismic Interpretation of Strike-Slip Faulting, Salt Tectonics, and Cretaceous Unconformities, Atlas Mountains, Central Tunisia," Journal of African Earth Sciences, Vol. 43, No. 4, 2005, pp. 464-486. doi:10.1016/j.jafrearsci.2005.09.010

[4] D. Tanfous, M. Bédir, M. Soussi, H. Azaiz, L. Zitouni, M. Inoubli and K. Ben Boubaker, "Halocinèse Précoce Associée au Rifting Jurassique dans l'Atlas Central de Tunisie," Comptes Rendus Géoscience, Vol. 337, No. 7, 2005, pp. 703-711. doi:10.1016/j.crte.2005.02.007

[5] M. Bédir, L. Zitouni, N. Boukadi, J. Saadi, R. Alouani, F. Ben Timzal, S. Tlig and C. Bobier, "Rifting, Halocinèse et Structuration des Bassins Péri-Téthysiens Jurassiques et Crétacé Inférieur de Subsurface du Domaine Atlasique Central de la Tunisie (Région de Gafsa-Sidi Ali Ben Aoun)," Africa Geosciences Review, Vol. 7, No. 3, 2000, pp. 289-306.

[6] S. Gassara, "Rapport sur les Disponibilités Hydrauliques du Bassin de Horchane Braga (Sidi Bouzid)," Rapport Direction Générale des Ressources en Eaux, Tunis, 1978.

[7] T. Zouaghi, M. H. Inoubli and M. Bédir, "Contribution of Seismic Velocities to the Structural and the Lithostratigraphic Studies: Salt-Intruded Corridor Ceiling and Lower Turonian Beida Anhydrite Deposits Outline in Central-Southern Atlas of Tunisia," Comptes Rendus Geoscience, Vol. 339, No. 1, 2007, pp. 13-23. doi:10.1016/i.crte.2006.12.002

[8] H. Azaïez, M. Bédir, D. Tanfous and M. Soussi, "Seismic Sequence Stratigraphy and Platform to Basin Reservoir Structuring of Lower Cretaceous Deposits in the Sidi AichMajoura Region (Central Tunisia)," Journal of African Earth Sciences, Vol. 48, No. 1, 2007, pp. 1-18. doi:10.1016/j.jafrearsci.2007.02.009

[9] M. Andrieux, "Prospection Electrique du Synclinal de Horchane-Braga," Rapport Direction Générale des Ressources en Eaux (DGRE), Tunis, 1978.

[10] T. Zouaghi, M. Bédir, H. Abdallah and M. H. Inoubli, "Seismic Sequence Stratigraphy, Basin Structuring, and Hydrocarbon Implications of Cretaceous Deposits (Albian-
Maastrichtian) in Central Tunisia," Cretaceous Research, Vol. 30, No. 1, 2009, pp. 1-21. doi:10.1016/i.cretres.2008.02.005

[11] L. Cagniard, "Reflection and Refraction of Progressive Seismic Waves," McGraw Hill, New York, 1962.

[12] S. Bouri, M. Gasmi, M. Jaouadi, I. Souissi, A. Lahlou Mimi and H. Ben Dhia, "Etude Intégrée des Données de Surface et de Subsurface Pour la Prospection des Bassins Hydrogéothermiques: Cas du Bassin de Maknassy (Tunisie Centrale)," Hydrological Sciences Journal, Vol. 52, No. 5, 2007, pp. 1298-1315. doi:10.1623/hysj.52.6.1298

[13] N. Boukadi and M. Bedir, "L'Halocinèse en Tunisie: Contexte Tectonique et Chronologie des Evènements," Comptes Rendus de l'Académie des Sciences, Vol. 322, No. 7, 1996, pp. 587-594.

[14] S. Chaibi, "Impact des Effets Anthropiques Sur la Nappe Phréatique de Sidi Bouzid," Université de Sfax, Mastère, 2004.

[15] F. Lachaal, M. Bédir, J. Tarhouni, A. Ben Gacha and C. Leduc, "Characterizing a Complex Aquifer System Using Geophysics, Hydrodynamics and Geochemistry: A New Distribution of Miocene Aquifers in the Zéramdine and Mahdia-Jébéniana Blocks (East-Central Tunisia)," Journal of African Earth Sciences, Vol. 60, 2011, pp. 222236. doi:10.1016/i.jafrearsci.2011.03.003

[16] L. Zitouni, "Evolution Géodynamique des Bassins Mésozoïques de Subsurface des Régions de Sidi Aïch-Majoura (Tunisie Centrale): Sismostratigraphie, Sismotectonique et Implications Pétrolières," Université Tunis II, Thèse, 1997, p. 335.

[17] S. Chaibi, N. Khlif, M. Chalbaoui and W. Aydi, "Chemical and Organic Contamination of Phreatic Aquifer of Sidi Bouzid (Central West of Tunisia)," Journal of Environmental Science and Engineering, Vol. 4, No. 5, 2010, pp. 1-8.

[18] M. Chalbaoui, "Caractérisation Structurale, Hydrogéologique et Hydrochimique des Principaux Bassins et Réservoirs du Sud Ouest de la Tunisie," Thèse d'état, Faculté des Sciences de Tunis, 2001, p. 213.

[19] A. Hlaiem, "Halokinesis and Structural Evolution of the Major Features in Eastern and Southern Tunisian Atlas," Tectonophysics, Vol. 306, No. 1, 1999, pp. 79-95. doi:10.1016/S0040-1951(99)00045-1

[20] M. Chalbaoui and H. Ben Dhia, "Principales Caractéristiques des Réservoirs du Sud-Ouest Tunisien," C. R. Géosciences, Vol. 336, No. 13, 2004, pp. 1191-1198.

[21] M. Chalbaoui, "Première Approche Pour L'Etude des Bassins Hydrogéologiques Profonds du Sud-Ouest Tunisien," Comptes Rendus Géoscience, Vol. 337, No. 16, 2005, pp. 1484-1491. doi:10.1016/j.crte.2005.09.001

[22] H. Chekhma and N. Ben Ayed, "Evolution Géodynamique des Bassins Crétacés Liés à L'Activité des Failles N-S (Région de Bir El Hafey-Sidi Ali Ben Aoun, Tunisie Centrale),"Office Nationale des Mines, Tunisie, 1998, p. 12.

[23] H. Azaiz, D. Tafnouz, H. Gabtni., M. Bédir and M. Soussi, "Integrated Geophysical Study of the Triassic Salt Bodies Geometry and Evolution in Central Tunisia," Comptes 
Rendus Geoscience, Vol. 340, No. 1, 2008, pp. 10-19. doi:10.1016/j.crte.2007.11.002

[24] W. M. Telford, L. P. Gedrart, R. E. Sherriff and D. A. Key, "Prospection Géophysique-Tome 1: Prospection sismique, University of Cambridge, Cambridge, 1976.

[25] R. Guellala, M. H. Inoubli, L. Moumni and T. Zouaghi, "Seismic Reflection Contribution to the Study of the Jerid Complexe Terminal Aquifer (Tunisia)," In: Dr. Hwee-San Lim, Ed., New Achievements in Geoscience, 2012.

[26] G. Henry, "La Sismique Réflexion, Principes et Développements," TECHNIP, France, 1997.

[27] J. L. Mari, F. C. Glangeaud and F. Coppens, "Traitement du Signal Pour Géologues et Géophysiciens: Techniques de Base," Volume 2, Publications de 1'Institut Francais de Pétrole, Montpellier, 2001.

[28] M. Jaffal, A. Kchikach, J.-P. Lefort and L. Hanich, "Contribution to Part of the Essaouira Basin (Morocco) by Seismic Reflection," C. R. Geosciences, Vol. 334, No. 4, 2002, pp. 229-234. doi:10.1016/S1631-0713(02)01756-X

[29] H. Gabtni, S. Alyahyaoui, C. Jallouli, W. Hasni and K. L. Mickus, "Gravity and Seismic Reflection Imaging of a Deep Aquifer in an Arid Region: Case History from the Jeffara Basin, Southeastern Tunisia," Journal of African Earth Sciences, Vol. 66-67, 2012, pp. 85-97. doi:10.1016/j.jafrearsci.2012.03.007
[30] F. Larroque and A. Dupuy, "Apports de la Méthode Sismique Réflexion Haute Resolution à l'Identification des Structures Profondes des Formations Tertiaires en Médoc (Gironde, France): Implications Hydrogéologiques," Comptes Rendus Géoscience, Vol. 336, No. 3, 2004, pp. 11111120 .

[31] V. Rădulescu, V. Rădulescu and F. Stan, “Geoelectrical Measurements Applied to the Assessment of Groundwater Quality," Geo-Eco-Marina, Vol. 12, No. 4, 2006, pp. 107-110.

[32] M. Bédir, "Mécanismes Géodynamiques des Bassins Associés aux Couloirs de Coulissement de la Marge AtLasique de la Tunisie: Sismo-Stratigraphie, Sismo-tec- Tonique et Implications Pétrolières," Thèse de Doctorat Es Sciences, Tunis, 1995, p. 412.

[33] S. Gassara, “Contribution à l'Etude Hydrogéologique du Bassin de Horchane-Braga," Thèse de Troisième Cycle, Université Pierre et Marie Curie, 1980, p. 80.

[34] M. Gasmi, "Apport de la Géophysique à la Reconnaissance et à la Gestion des Ressources Naturelles, Application en Tunisie," Thèse d'état, Université de Sfax, ENIS, Sfax, 2002, p. 471.

[35] A. Hajjem, "Etude Hydrogéologique de la Nappe Profonde de Horchane," Rapport CRDA Sidi Bouzid, DGRE, Tunis, p. 28. 